\title{
Rancang Bangun Aplikasi Pengenalan Satwa Langka di Indonesia Menggunakan Augmented Reality
}

\author{
Christian O. Karundeng ${ }^{1)}$, Dringhuzen J. Mamahit ${ }^{2)}$, Brave A. Sugiarso ${ }^{3)}$ \\ Teknik Informatika Universitas Sam Ratulangi Manado, Jl. Kampus Bahu-Unsrat Manado, 95115 \\ 13021106081@student.unsrat.ac.id ${ }^{1)}$,dringhuzen_mamahit@unsrat.ac.id ${ }^{2)}$,brave@ unsrat.ac.id ${ }^{3)}$
}

\begin{abstract}
Abstrak - Augmented Reality merupakan suatu teknologi yang dapat dimanfaatkan dalam pengembangan aplikasi saat ini, dengan adanya Augmented Reality pengguna akan mendapatkan bentuk visual 3D suatu objek sehingga informasi yang terkandung dalam aplikasi dapat diserap dengan baik. Indonesia terkenal akan keanekaragaman satwa yang tersebar di pulaupulau di Indonesia, namun sebab kurangnya media untuk memperkenalkan satwa langka di Indonesia menjadikan satwa langka yang ada tidak dikenal sehingga rentan akan perburuan sehingga terancam punah. Tujuan penelitian ini adalah untuk membangun sebuah aplikasi Smartphone berbasis Android yang memperkenalkan satwa langka yang ada di Indonesia. Aplikasi ini diberi nama "Aria". Aplikasi ini menggunakan Augmented Reality dengan metode Markerless Augmented Reality menjadikan aplikasi ini mudah digunakan dimana saja. Aplikasi ini berbasis Android. Metode perancangan yang digunakan adalah MDLC (Multimedia Development Life Cycle) yang terbagi dalam 6 tahap, yaitu : Concept, Design, Material collecting, Assembly, Testing, dan Distribution. Pembuatan aplikasi ini menggunakan software yang open source (terbuka), yaitu Blender dan Unity yang digunakan untuk pembuatan objek 3 dimensi satwa langka beserta animasi dan pembuatan aplikasi berbasis Android. Dalam penelitian dapat diketahui bahwa Augmented Reality dapat digunakan sebagai media pengenalan satwa langka di Indonesia, diharapkan aplikasi ini selanjutnya bisa dikembangkan untuk berbagai platform juga dapat memuat informasi tentang seluruh satwa langka yang ada di Indonesia.
\end{abstract}

Kata kunci - Augmented Reality, Android, Blender, MDLC, Satwa Langka, Unity3D.

Abstract - Augmented Reality is a technology that can be utilized in the development of applications today, with the Augmented Reality users will get a 3D visual form of an object so that the information contained in the application can be absorbed properly. Indonesia is famous for the diversity of animals spread across the islands of Indonesia, but because of the lack of media to introduce endangered species in Indonesia rare animals that are not known so vulnerable to hunting so endangered. The purpose of this study is to build an Android-based Smartphone application that introduces endangered species in Indonesia. This app is named "Aria". This application using Augmented Reality with Markerless Augmented Reality method makes this application easy to use anywhere. This app is Android based. Design method used is MDLC (Multimedia Development Life Cycle) which is divided into 6 stages, namely: Concept, Design, Material Collecting, Assembly, Testing, and Distribution. Making this application using open source software, namely Blender and Unity are used to create 3-dimensional objects of rare animals and animation and manufacture of Android-based applications. In the research can be known that Augmented Reality can be used as a medium of introduction of endangered species in Indonesia, this application is expected to be developed for various platforms can also contain information about all the rare animals in Indonesia.

Keywords - Augmented Reality, Android, Blender, MDLC, Satwa Langka, Unity3D.

\section{Pendahuluan}

Indonesia merupakan suatu negara yang terkenal akan kekayaan sumber daya alam dan keanegaraman satwa. Di Indonesia terdapat bermacam-macam jenis satwa langka yang tersebar di berbagai pulau Indonesia. Satwa langka merupakan istilah yang diberikan untuk hewan yang terancam punah keberadaannya. Kelangkaan ini disebabkan oleh keserakahan dan perbuatan manusia yang merusak ekosistem dan habitat satwa demi keuntungan pribadi serta untuk memperluas daerah pemukiman yang ada. Satwa langka sering diburu untuk di jadikan hiasan, hewan peliharaan juga dimanfaatkan kulitnya menjadi suatu karya seni yang bernilai tinggi. Hal ini mengakibatkan keberadaan satwa langka terancam punah.

Satwa langka seharusnya dilindungi dan dilestarikan oleh pemerintah juga masyarakat karena hal tersebut merupakan suatu kewajiban yang memerlukan kerja sama dalam mengatasi ancaman yang ada. Akan tetapi kurangnya kepedulian dan besarnya keingintahuan menjadi hal yang serius dalam permasalahan ini. Pengetahuan yang memadai serta kesulitan dalam mendapatkan informasi menjadi salah satu faktor penyebabnya. Pada era ini, penyebaran informasi melalui buku ataupun media tulis lainnya masih belum cukup dalam meningkatkan rasa keingintahuan masyarakat [1]. Interaksi antara manusia dan alam sekitarnya sangat diperlukan guna membangun suatu hubungan dan daya tarik juga merupakan suatu hal yang penting. Jika hal ini terus-menerus terjadi maka dapat dipastikan kepunahan yang menjadi 
ancaman selama ini akan benar-benar terjadi. Dengan demikian diperlukan sebuah teknologi yang mampu memberikan informasi secara mudah serta dapat menampilkan bentuk 3 dimensi satwa langka secara visual.

Augmented Reality (AR) merupakan teknologi yang dapat menggabungkan dunia nyata dan dunia virtual serta dapat menambahkan dunia nyata dengan objek-objek maya di dalamnya [2]. Pada umumnya aplikasi Augmented Reality memerlukan marker khusus untuk menjalankannya. Karena menggunakan Marker Based Augmented Reality yang hanya dapat dijalankan jika marker yang dibutuhkan tersedia, menjadikan aplikasi terbatas pada penggunaan marker khusus saja sehingga tidak efisien untuk digunakan. Penerapan Markerless Augmented Reality menjadi solusi yang tepat dalam hal ini sebab tidak memerlukan marker khusus untuk mejalankannya. Markerless Augmented Reality dapat membuat marker sendiri yang akan terbentuk secara otomatis dengan cara memindai sebuah objek yang dipilih dengan menggunakan kamera. Karena penggunaanya yang praktis user dapat dengan mudah menggunakan aplikasi [3].

Dalam hal ini peneliti berkeinginan membuat suatu aplikasi untuk memperkenalkan satwa langka di Indonesia dengan menggunakan teknologi Augmented Reality. Dengan menerapkan metode Markerless Augmented Reality menggunakan User Defined Target pengguna dapat menggunakan aplikasi ini kapanpun dan dimana saja. Pengunaan User Defined Target memungkinkan user dapat memilih objek yang akan dijadikan marker dengan cara melakukan scan dengan menggunakan kamera yang tersedia pada smartphone. Dengan ini user tidak perlu lagi khawatir akan ketersediaan marker khusus dalam menjalankan aplikasi ini sehingga akan mempermudah user untuk mendapatkan informasi serta bentuk visual satwa langka. Augmented Reality yang menyajikan bentuk tiga dimensi (3D) dan animasi satwa yang membuat objek seakan-akan nyata sehingga dapat menarik perhatian user untuk mengenal dan mempelajarinya. Augmented Reality sendiri dapat di akses melalui Smartphone berbasis Android yang sudah banyak digunakan orang pada saat ini, dan juga sudah terkenal di seluruh dunia karena merupakan platform yang terbuka bagi pengembang dan pencipta aplikasi.

\section{A. Satwa Langka}

Satwa langka adalah sebutan untuk satwa yang terancam punah dari habitat aslinya. Kelangkaan sendiri terjadi karena ulah manusia yang memanfaatkan sumberdaya alam secara berlebihan, seperti melakukan penebangan liar disebagian besar kawasan hutan yang mengakibatkan rusaknya ekosistem yang ada. Hal ini dilakukan hanya untuk memenuhi kebutuhan dan keinginan pribadi seperti mengambil alih fungsi hutan sebagai pemukiman yang berdampak hilangnya habitat dari satwa. Kehilangan habitat asal mengakibatkan satwa sulit untuk berkembang biak juga kesulitan dalam beradaptasi dengan lingkungan, sehingga memperbesar angka kematian satwa tersebut. Belum lagi dengan adanya perburuan liar yang dilakukan oleh oknumoknum yang tidak bertanggung jawab, yang mengakibatkan berkurangnya populasi satwa secara drastis. Pemanfaatan tulang belulang dan kulit hewan yang dijadikan sebagai hiasan dan pakaian merupakan karya seni yang mempunyai nilai jual yang tinggi sehingga mengakibatkan satwa sering dicari dan banyak diburu.

\section{B. Augmented Reality}

Augmented Reality (AR) merupakan sebuah teknik untuk menggabungkan dunia nyata dengan dunia lain, dan memungkinkan sebuah objek di dunia maya ditampilkan dengan objek lain di dunia nyata secara bersamaan [4]. Azuma (1997) mendefinisikan Augmented Reality sebagai penggabungan benda-benda nyata dan maya di lingkungan nyata, yang berjalan secara interaktif dalam waktu nyata (real time). Augmented Reality adalah realitas tambahan yang dapat melengkapi kenyataan berbeda dengan Virtual Reality yang benar-benar menggantikan kenyataan. Perkembangan Augmented Reality telah menjangkau ke berbagai aspek kehidupan. Dengan Augmented Reality dapat membuat suatu objek mati seakan-akan dihidupkan dengan bantuan kamera yang dapat diakses di komputer atau smartphone. Dengan sebuah marker kita dapat melihat benda dua dimensi atau tiga dimensi dalam sebuah layar sebagai titik acuan fokus kamera [5]. Berikut ini merupakan teknik penggunaan Augmented Reality beserta penjelasannya :

\section{1) Marker Augmented Reality (Marker Based Tracking)}

Marker Based Tracking merupakan salah satu metode yang digunakan pada Augmented Reality. Metode ini memerlukan marker khusus yang merupakan suatu ilustrasi hitam dan putih persegi dengan batas hitam tebal dan latar belakang yang berwarna putih. Dengan menggunakan kamera yang dapat diakses pada perangkat komputer atau smartphone. posisi dan orientasi objek marker tersebut dapat dikenali sehingga dapat menciptakan sebuah dunia virtual 3D yaitu titik $(0,0,0)$ dan sumbu yang terdiri atas $X$, $\mathrm{Y}$ dan Z [6].

\section{2) Markerless Augmented Reality}

Markerless Augmented Reality adalah metode dimana pengguna tidak perlu lagi menggunakan sebuah marker untuk menampilkan elemen-elemen digital. Teknik-teknik yang dapat digunakan dengan menggunakan Markerless Tracking, yaitu:

\section{a. Face Tracking}

Face Tracking merupakan teknik yang memungkinkan perangkat dapat mengenali bagian wajah manusia dari fitur wajah seperti posisi mata, 
hidung, mulut serta mengabaikan objek - objek lain yang ada di sekitarnya.

b. 3D Object Tracking

3D Object Tracking merupakan teknik yang dapat mengenali semua bentuk benda yang ada, seperti bentuk mobil, rumah, meja, dan sebagainya.

c. Motion Tracking

Motion Tracking merupakan teknik yang dapat menangkap gerakan, dimana teknik ini biasa digunakan untuk pembuatan film -film animasi dan mencoba mensimulasikan gerakan.

d. GPS Based Tracking

GPS Based Tracking memanfaatkan fitur GPS dan kompas yang ada pada perangkat dan mengambil data berupa posisi koordinat perangkat, kemudian secara real time akan memberikan tampilan dalam bentuk arah yang diinginkan.

e. User Defined Target

User Defined Target adalah Image Target (gambar penanda) yang terbuat pada saat runtime dari frame kamera yang dipilih oleh user. Atau dengan kata lain, User Defined Target merupakan Marker yang terbentuk pada saat kamera memindai suatu target [3].

\section{Blender}

Blender adalah software gratis (freeware) dan terbuka (open source) maka siapa saja dapat merombak tampilan dan fungsinya [7]. Karena proses instalasinya yang sangat mudah dan tidak membutuhkan register, crack, serial number,formulir dan proses lainnya yang membingungkan, menjadikan Blender sebagai pilihan utama semua orang. Blender mempunyai ukuran file yang relatif kecil kurang lebih $50 \mathrm{MB}$ sehingga dapat menghemat penyimpanan.

\section{Unity Game Engine}

Menurut Roedavan (2016), Unity adalah game engine yang memungkinkan anda, baik perseorangan maupun tim, untuk membuat sebuah game 3D dengan mudah dan cepat. Unity digunakan untuk pembuatan game seperti First Person Shooting (FPS), Role Playing Game (RPG) dan Real Time Strategy (RTS). Unity dapat dibangun diberbagai platform, seperti: Windows, Mac, Android, IOS, PS3 dan Wii.

\section{E. Vuforia}

Vuforia adalah Software Development Kit (SDK) yang digunakan untuk membuat aplikasi Augmented Reality. Vuforia menggunakan teknologi Computer Vision untuk mengenali dan melacak marker atau image target. Vuforia tersedia untuk berbagai platform, seperti android, ios dan untuk aplikasi game engine Unity 3D. Vuforia dapat diakses dengan mudah hampir pada semua smartphone dan tablet, karena memberikan kebebasan untuk para pembuat dan pengembang aplikasi [8].

\section{F. $\quad$ Multimedia Development Life Cycle (MDLC)}

Pada metode atau langkah-langkah perancangan Multimedia Development Life Cycle (MDLC) terdapat 6 langkah atau tahapan, yaitu : Concept, Design, Material Collecting, Assembly, Testing, dan Distribution [9].

1). Concept Concept (konsep) adalah tahap untuk menentukan tujuan siapa pengguna (identifikasi audience), macam aplikasi (presentasi, interaktif, dan lainlain), tujuan aplikasi, dan spesifikasi umum.

2). Design

Design (perancangan) adalah tahap membuat gambaran dari aplikasi yang berupa ide, tema serta tampilan yang akan dibuat.

\section{3). Material Collecting}

Material Collecting (pengumpulan bahan) adalah tahap dimana peneliti mengumpulkan bahan yang dibutuhkan dalam pembuatan aplikasi .

\section{4). Assembly}

Assembly (pembuatan) adalah tahap di mana semua objek atau bahan untuk membuat aplikasi dibuat dan digabungkan sehingga menghasilkan sebuah aplikasi.

5). Testing

Testing (pengujian) adalah tahap yang dilakukan setelah proses assembly dengan tujuan untuk mengetahui apakah aplikasi dapat berjalan dengan baik dan semestinya, juga untuk mencari kesalahan atau adanya error dalam menjalankan aplikasi tersebut.

\section{6). Distribution}

Distribution (distribusi) adalah tahap yang dilakukan setelah proses testing dan di lakukan publish agar supaya pengguna dapat menggunakannya.

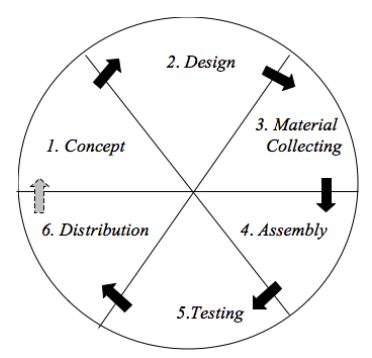

Gambar 1 Multimedia Development Life Cycle

\section{METODOLOGI PENELITIAN}

\section{A. Kerangka Kerja}

Kerangka kerja adalah pola pikir yang dibuat dalam proses penelitian agar terstruktur dengan baik. Gambar 2 merupakan proses dalam pembuatan penelitian ini. 


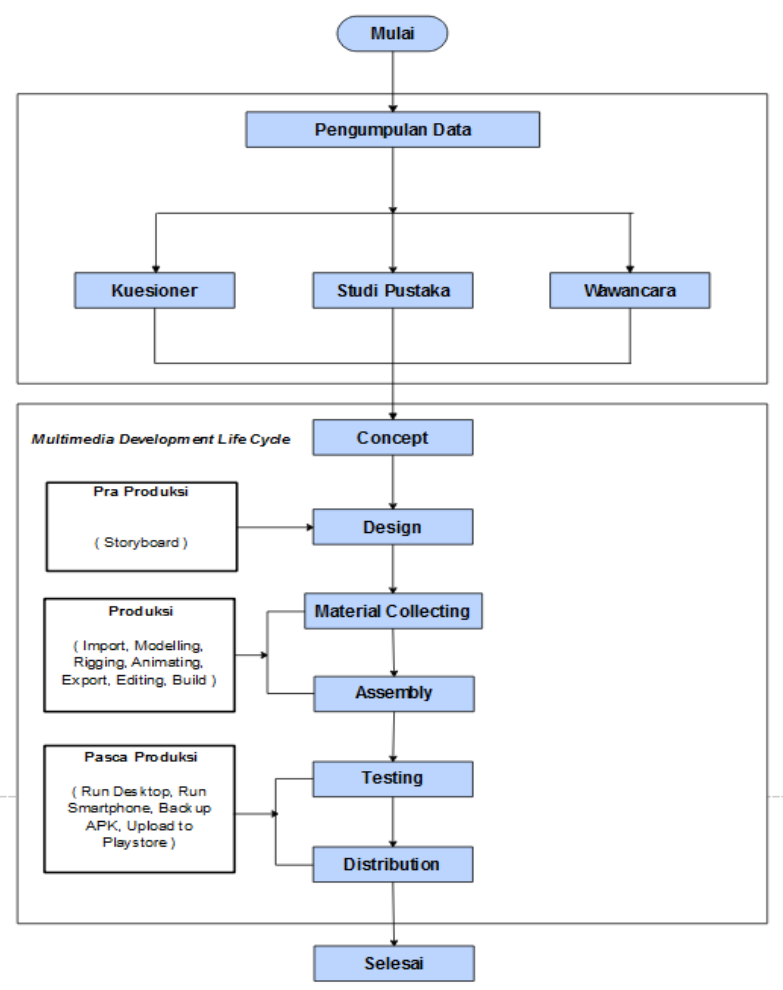

Gambar 2 Kerangka Kerja

B. Konsep

Pada tahap ini dilakukan 3 macam pemgumpulan data yaitu, kuesioner, studi pustaka dan wawancara. Berikut merupakan rincian dan penjelasan masing-masing pengumpulan data :

\section{1) Kuesioner}

Penulis melakukan pencarian informasi dengan cara menyebarkan kuesioner agar dapat mengetahui pengetahuan dan kebutuhan masyarakat tentang satwa langka di Indonesia.

\section{2) Studi Pustaka}

Penulis mengambil data dari berbagai sumber, antara lain, jurnal, buku, internet yang memuat tentang satwa langka yang ada di Indonesia.

\section{3). Wawancara}

Wawancara dilakukan untuk mendapatkan data-data secara langsung dari narasumber yang berkaitan langsung dengan topik yang diambil. Penulis melakukan wawancara dengan Ibu. Telly Gumolung yang merupakan salah satu pengelola taman margasatwa tandurusa bitung Sulawesi utara.

\section{Perancangan}

Pembuatan UML dan Storyboard yang menunjukkan cara pengguna berinteraksi dengan aplikasi serta merupakan acuan tampilan aplikasi beserta fungsinya.

\section{1) Use Case}

Use case secara sederhana sesungguhnya merupakan sebuah sarana bantu untuk mendefinisikan apa yang ada di luar sistem (aktor) dan apa yang harus dilakukan oleh sistem yang sedang dikembangkan [10] (lihat gambar 3).

\section{2) Storyboard}

Perancangan Storyboard merupakan tahapan yang penting dalam pembuatan aplikasi karena dapat menentukan elemen-elemen pendukung yang akan di tampilkan pada aplikasi. Perancangan ini berfungsi sebagai acuan penulis dalam membuat aplikasi . Perancangan ini berisikan rincian informasi serta desain dari tiap-tiap tampilan aplikasi (Lihat gambar 4).

\section{Material Collecting}

Dalam tahap ini merupakan tahap dimana pengguna mendesain interface menggunakan Adobe photoshop serta memodelkan 3D yang di dapat dari internet, yaitu websitewebsite penyedia objek 3D gratis, seperti: www.turbosquid.com dan www.cadnav.com, Lalu menggunakan software Blender untuk meng-import dan pembuatan rigging beserta animasi 3D.

\section{1) Objek Satwa Langka}

Pembuatan dari model 3D satwa langka ini menggunakan aplikasi Blender. Dengan mengikuti gambar aslinya sehingga dibuatlah 5 3D model satwa langka yang merupakan perwakilan dari setiap pulau di Indonesia. Dalam pembuatan modelling 3D satwa, terdapat 1 satwa yang dibuat menggunakan Blender, sisanya merupakan model yang di download dari internet dan Asset 3D yang dibeli dari Unity store (lihat gambar 5).

\section{E. Assembly}

Merupakan tahap pembuatan aplikasi dimana data-data atau file-file yang sudah dibuat dan dikumpulkan disusun menjadi sebuah file dengan menggunakan aplikasi Unity.

\section{1) Modelling $3 D$}

Gambar 6 merupakan model 3D dari Coelacanth Sulawesi (Latimeria Menadoensis) yang merupakan 3D model yang dibuat dari awal dalam bentuk cube dengan aplikasi Blender. Model yang telah terbentuk diberikan teksturing berupa gambar ikan Coelacanth seperti aslinya karena merupakan gambar berformat .jpg yang di download dari internet. Setelah itu model 3D yang telah selesai diberikan Rigging (pemberian tulang) berjumlah 10 tulang dan siap untuk di animasikan sesuai dengan gerakan ikan pada umumnya. Selanjutnya model 3D yang telah diberikan Rigging (pemberian tulang) dan animasi di simpan untuk tahap selanjutnya, sehingga 3D model dari Coelacanth dapat digunakan dalam aplikasi pengenalan satwa langka Indonesia.

2) Import Asset 
Asset yang telah dikumpulkan kemudian di import ke dalam unity (lihat gambar 7), setelah itu dibuat masing-masing scene menu aplikasi untuk dimasukan asset yang telah di import tersebut. Setelah asset dan scene berhasil di gabungkan, maka akan masuk pada tahap selanjutnya.

\section{3) Build Aplikasi Android}

Gambar 8 merupakan proses pembuatan (build) aplikasi Android dalam software Unity. Setelah asset dan scene di gabungkan kemudian di build sehingga menghasilkan sebuah aplikasi pengenalan satwa langka di Indonesia menggunakan Augmented Reality berbasis Android dengan format APK. Aplikasi ini dapat digunakan pada smartphone berbasis Android.

\section{F. Tahap Pengujian aplikasi (Testing)}

Adalah tahap yang digunakan untuk menguji aplikasi dan untuk mengetahui apakah aplikasi dapat digunakan dan berjalan dengan baik. Tahap pengujian dilakukan pada desktop (menggunakan unity mode game) dan smartphone ( setelah aplikasi di build ke sistem operasi Android) (lihat gambar 9).

\section{G. Distribusi (Distribution)}

Merupakan tahan penyimpanan aplikasi kedalam media penyimpanan seperti hardisk dan smartphone ataupun mendistribusikannya dengan cara melakukan upload ke Android Playstore (lihat gambar 10).

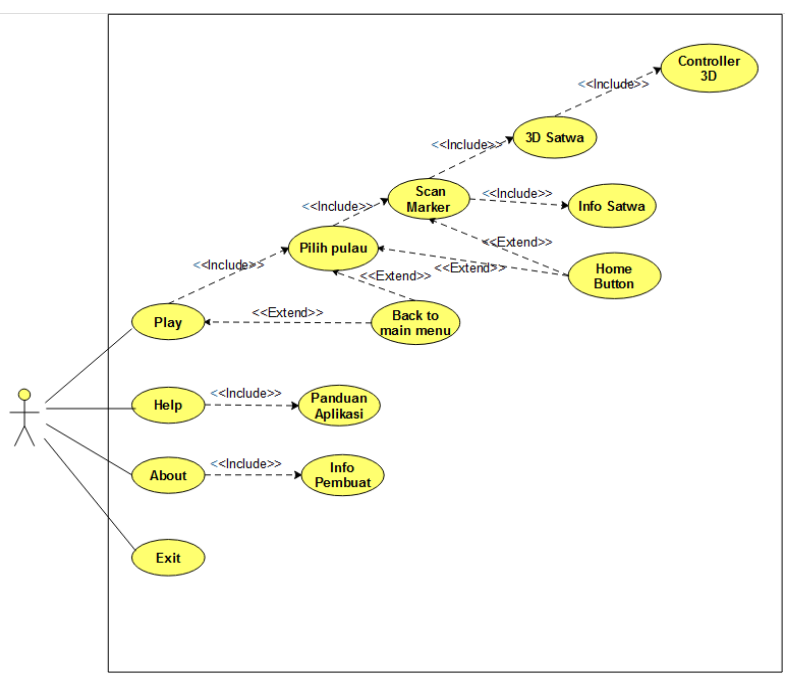

Gambar 3 Use Case Diagram

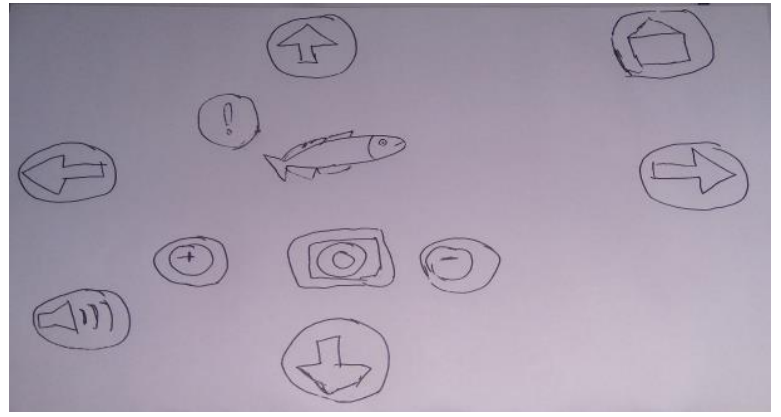

Gambar 4 Storyboard Play

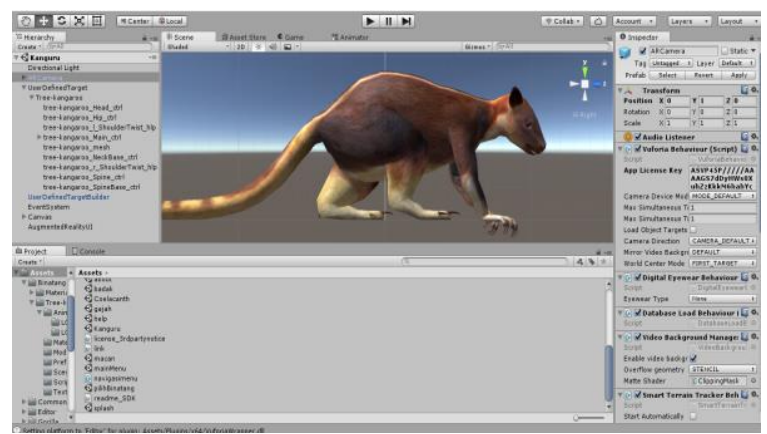

Gambar 5 Asset 3D Unity Play Store

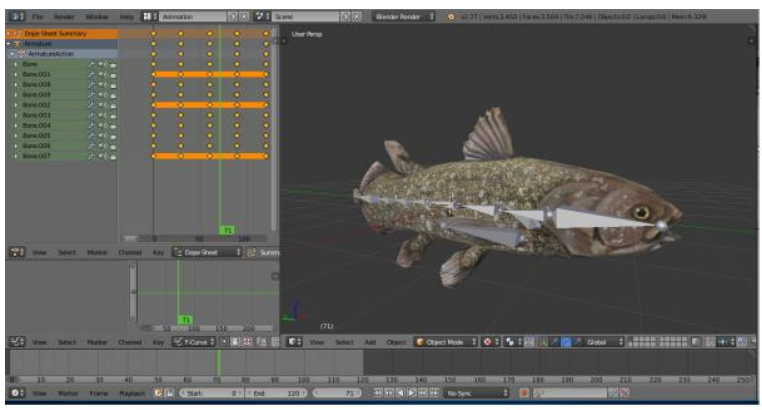

Gambar 6 Coelacanth 3D modelling

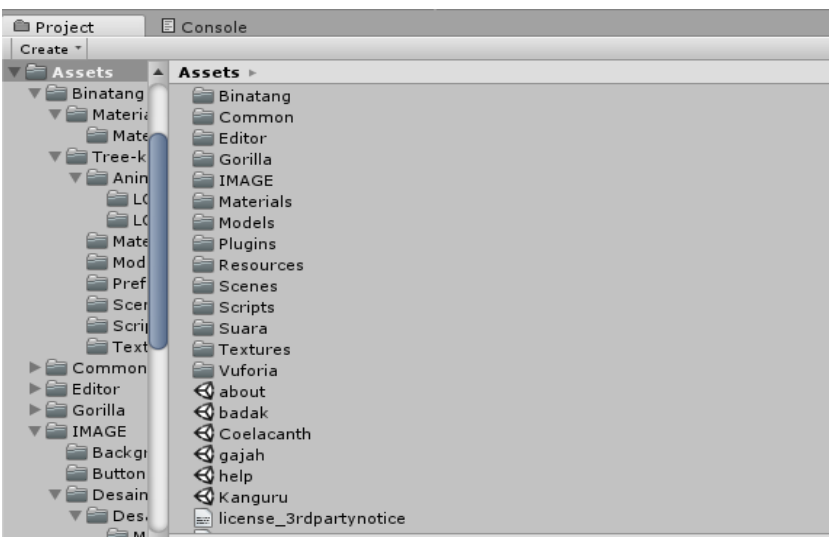

Gambar 7 Import Asset

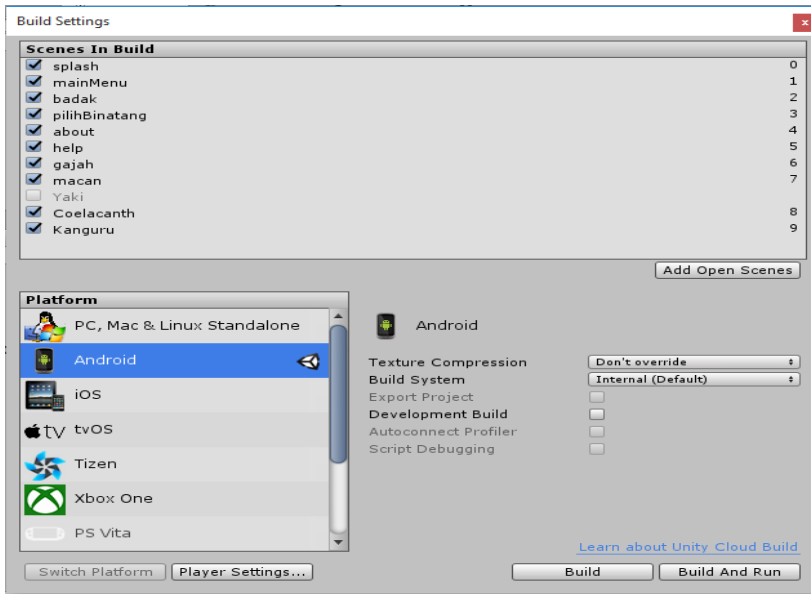

Gambar 8 Proses Build Aplikasi Android 


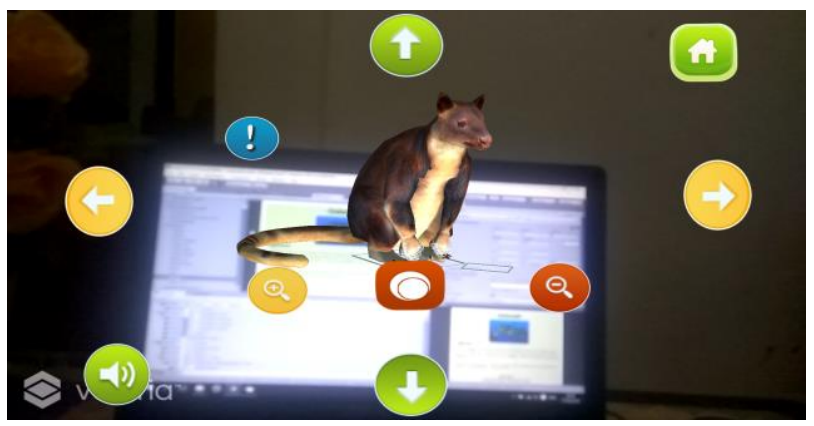

Gambar 9 Tampilan Objek Kanguru Pada Smartphon

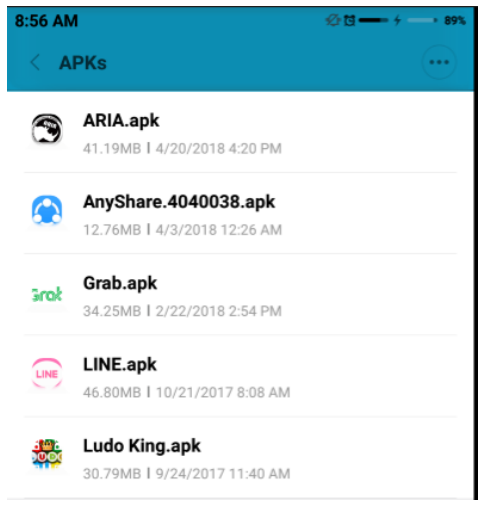

Gambar 10 Aplikasi Pada Smartphone

\section{HASIL DAN PEMBAHASAN}

\section{A. Interface ( Tampilan Aplikasi)}

Tampilan berdasarkan storyboard yang telah dibuat, yaitu tampilan splash screen (lihat gambar 11), main menu (lihat gambar 12,13,19,20) dan informasi dari 5 hewan (lihat gambar 14-18).

Gambar 11 merupakan design interface dari splash screen dari aplikasi pengenalan satwa langka di Indonesia. Dalam tampilan ini, terdapat judul, logo aplikasi, logo Unsrat, logo unity .

Gambar 12 merupakan design interface dari menu utama (home). Pengguna dapat memilih salah satu dalam menu utama.

Gambar 13 merupakan storyboard dari menu pilih pulau yang berfungsi untuk menampilkan scene scan marker.

Gambar 14 merupakan design interface (tampilan) dari informasi mengenai satwa langka di Indonesia yaitu, Macan dahan Kalimantan (Neofelis Diardi).

Gambar 15 merupakan design interface (tampilan) dari informasi satwa langka di Indonesia yaitu, Gajah sumatera (Elephas maximus sumatranus).
Gambar 16 merupakan design interface (tampilan) dari informasi satwa langka di Indonesia yaitu, Badak jawa (Rhinoceros Sondaicus)

Gambar 17 merupakan design interface (tampilan) dari informasi mengenai satwa langka di Indonesia, Coelacanth (Latimeria Menadoensis).

Gambar 18 merupakan design interface (tampilan) dari informasi satwa langka di Indonesia yaitu, Kanguru pohon (Dendrolagus sp).

Gambar 19 merupakan tampilan menu help (panduan) dalam aplikasi.

Gambar 20 merupakan tampilan menu about dalam aplikasi.
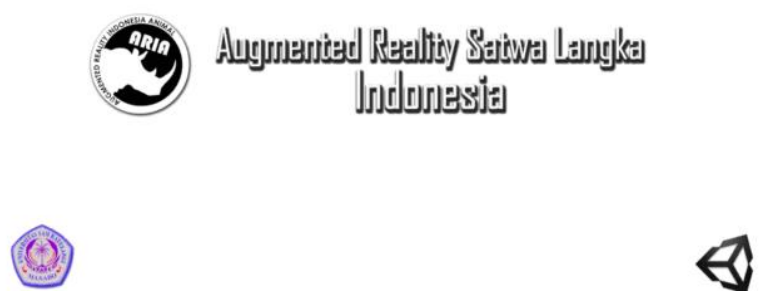

Gambar 11 Splash Screen

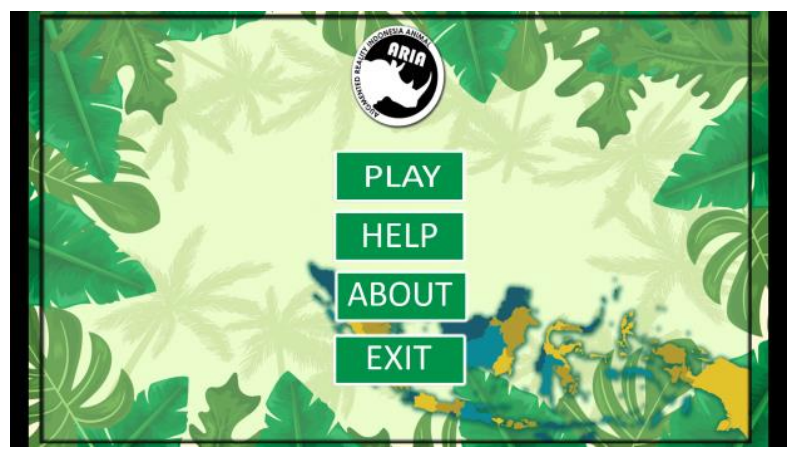

Gambar 12 Interface Menu Utama

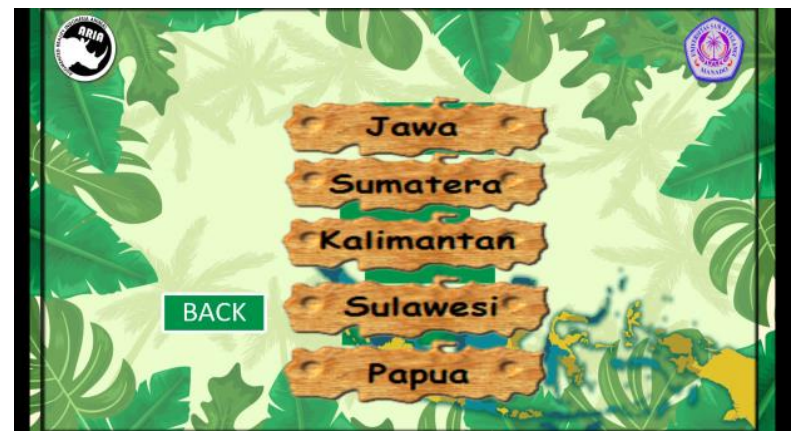

Gambar 13 Interface Menu Pilih Pulau 


\section{Macan Dahan Kalimatan}

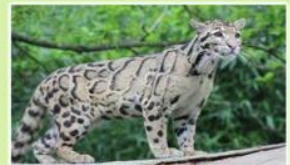

Informasi

Macan dahan (Neofelis diardi) adalah spesies kucing berukuran sedang yang hanya ditemukan di Sumatera dan Kalimantan. Macan dahan memiliki badan yang kekar dengan berat 12-25 kg sedangkan panjanggnya 90 cm. pola bulunya berupa oval tidak beraturan dengan sisi tepi hitam. Macan dahan panjanggnya
sekarang sudah menjiadi langka dan terancam punah. IUCN memasukkan satwa ini dalam Red List dengan status vulnerable atau rentan kepunahan. Satwa ini juga terancam oleh perburuan dan konflik

Gambar 14 Interface informasi Macan Dahan

Gajah Sumatera

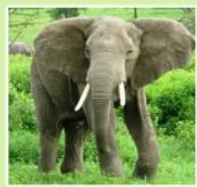

Informasi

Gajah memiliki kulit berwarna abu-abu bercampur dengan warna coklat. Kulit gajah sangat tebal. dan kering terdapat rambut-rambut halus di seluruh tubuhnya. Jejak kaki pada gajah sumater dewasa berukuran antara $35-44 \mathrm{~cm}$, dan pada jejak kaki gajah muda berukuran antara $18-22 \mathrm{~cm}$.

Gajah sumatera merupakan hewan langka yang harus dilindungi. Namun hingga saat ini keberadaan jumlah populasi gajah sumatera makin menurun akibat berbagai ancaman terhadap habitatnya dan perburuan.

Gambar 15 Interface Informasi Gajah

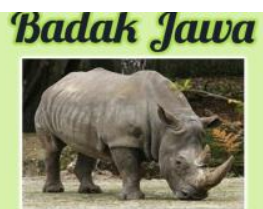

\section{Informasi}

Spesies ini juga disebut badak bercula satu kecil. Badak jawa mirip dengan badak India yang lebih besar, dan pernah jadi badak yang paling banyak ditemukan di Asia. Sayangnya badak jawa telah diburu untuk diambil culanya sehingga kini merupakan salah satu hewan paling langka di Bumi.

Gambar 16 Interface Informasi Badak

\section{Informasi}

Publikasi tentang temuan coelacanth Sulawesi ini pertama kali dimuat dalam jurnal ilmiah Nature tanggal 24 September 1998 . Tim peneliti gabungan Indonesia dan Perancis akhirnya menobatkan nama ikan raja laut ini sebagai Latimeria menadoensis, spesies baru bagi ilmu pengetahuan. Spesies baru ini berbeda dengan yang ada di pantai Afrika Timur.

Analisis DNA menunjukkan bahwa Latimeria menadaensis ini dalam perkembangannya mulai memisahkan diri dari Latimeria chalumnae sekitar $1.8-11.0$ juta tahun silam.
Kanguru Pohon Papua

\section{Informasi}

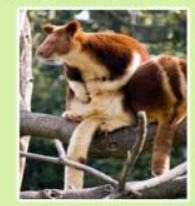

Kanguru pohon (Dendrolagus sp) adalah salah satu satwa endemic Papua vang merupakan salah satu dari dua jenis mamalia darat terbesar di Papua yang telah dikenal dan dimanfaatkan oleh masyarakat Papua. Hewan ini termasuk dalam family Macropopidae dan masuk dalam daftar hewan langka (endangered) menurut IUCN. Secara fisik, kanguru pohon ini memiliki ukuran tubuh yang lebih kecil dibandingkan ukuran tubuh kangguru Secara fisik, kanguru pohon ini memiliki ukuran tubuh yang lebih kecil dibandingkan ukuran tubuh
Australia. Kangguru ini memiliki bulu cokelat kemerahan dengan kambinasi putih di bagian dadanya.

Kelestarian hewan ini semakin mengkhawatirkan dikarenakan populasinya yang semakin menurun hingga $50 \%$ selama lebih dari 3 dekade ini karena peningkatan aktifitas manusia seperti berburu dan bercocok tanam.

Gambar 18 Interface Informasi Kanguru

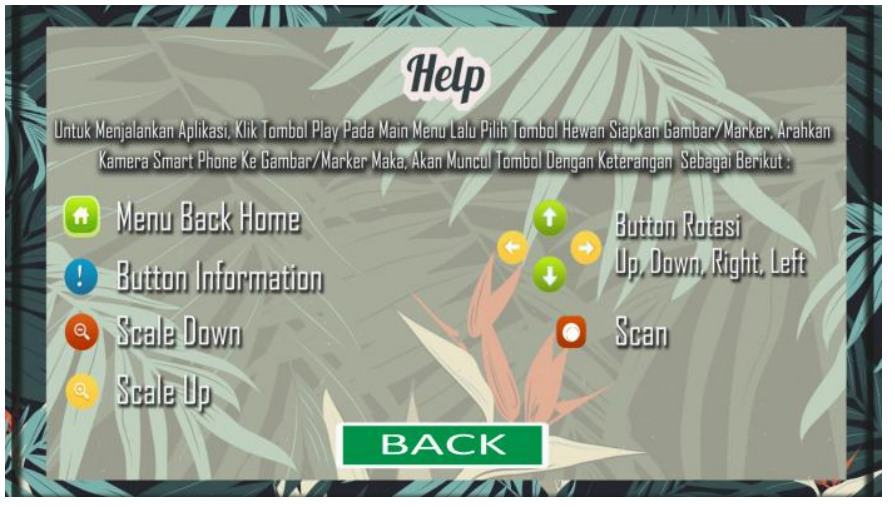

Gambar 19 Interface Menu Help

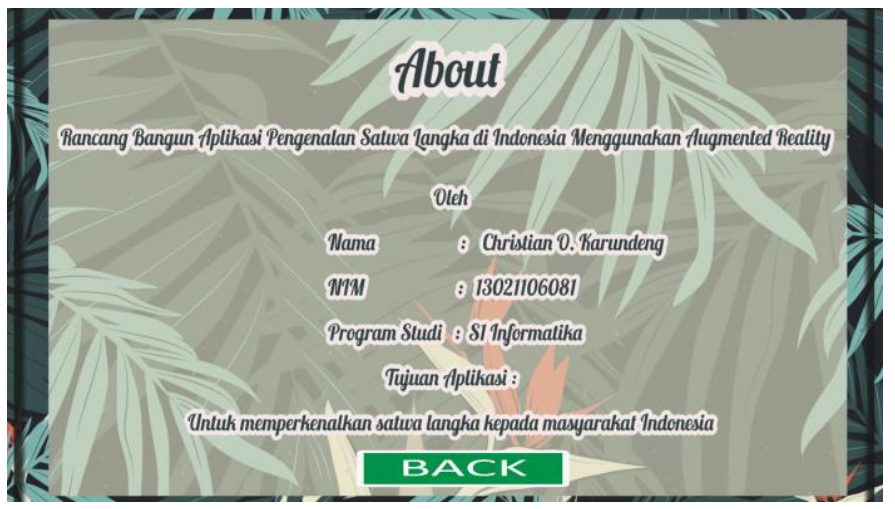

Gambar 20 Interface Menu About

\section{KESIMPULAN DAN SARAN}

\section{A. Kesimpulan}

Setelah penulis melakukan pengumpulan data yang dibutuhkan guna membuat Aplikasi Augmented Reality satwa langka indonesia hingga menyelesaikan proses pembuatan aplikasi ini maka penulis dapat menarik kesimpulan sebagai berikut : 
1) Aplikasi pengenalan satwa langka di Indonesia dapat dijalankan pada smartphone berbasis Android menggunakan metode Markerless Augmented Reality dengan pemindaian dengan posisi datar (Horizontal) pada marker yang berupa gambar yang dicetak maupun gambar digital pada gadget.

2) Jarak marker kurang lebih 20 - $30 \mathrm{~cm}$ dari kamera tergantung pada ukuran marker itu sendiri.

3) Aplikasi Augmented Reality satwa langka Indonesia ini bisa menjadi sarana penyampaian informasi dan teknologi yang menarik untuk memperkenalkan satwa langka di Indonesia.

\section{B. Saran}

Selama proses pembuatan aplikasi Augmented Reality satwa langka Indonesia ini penulis mendapatkan banyak sekali hambatan-hambatan yang penulis temukan, maka dari itu penulis menyarankan agar:

1) Dalam pembuatan Aplikasi AR satwa langka ini sebaiknya menggunakan komputer/laptop dengan perangkat yang mempunyai spesifikasi tinggi.

2) Sebaiknya dalam pembuatan Aplilkasi AR satwa langka Indonesia dilakukan dalam bentuk tim agar waktu yang penyelesaian bisa lebih cepat.

\section{DAFTAR REFERENSI}

[1] A. Franz , U. Lestari, D. Andayati. Augmented Reality Untuk Pengenalan Satwa Pada Kebun Binatang Gembira Loka Yogyakarta. Jurnal Script, Vol. 1, No. 2. 2014.

[2] F. S. Efendi, A. Izzah, dan Sudarmaji. Sistem Informasi Geografis Untuk Pendataan Sebaran Satwa Langka di Indonesia. TeknologiVol.6, No.1, :172-177. 2016.

[3] H. Hendratman. " The Magic Of Blender 3d Modelling". Informatika Bandung. 2017.

[4] M. I. Maramis. Augmented Reality Pada Aplikasi Android Untuk Memperlihatkan Gedung Fatek. Fakultas Teknik Universitas Sam Ratulangi. Manado. 2016.

[5] R.T. Azuma. " A Survey Of Augmented Reality" . Teleoperators and Virtual Environments, Vol. 6, No. 4, 355-385. 1997.

[6] R. Gusman, M. E. Apriyani. Analisis Pemanfaatan Metode Markerless User Defined Target Pada Augmented Reality Sholat Subuh. 2016.

[7] R. F. Raranta, A. A. E. Sinsuw , B. A. Sugiarso. Pengenalan Teks Pada Objek-Objek Wisata di Sulawesi Utara Dengan Teknologi Augmented Reality. E-Journal Teknik Informatika Vol. 12, No. 1. 2017.

[8] R. Roedavan. Unity : Tutorial Game Engine. Informatika Bandung. 2016.
[9] S. Lazuardy. Augmented Reality : Masa Depan Interaktivitas. [Online]. Available http://tekno.kompas.com/read/2012/04/09/12354384/augmented.realit y.masa.depan.interaktivitas. Diakses pada tanggal 20 April 2017.

[10] S. R. Pressman. Rekayasa Perangkat Lunak - Pendekatan Praktisi Edisi 7 - Buku 1. Yogyakarta: Penerbit Andi. 2012.

\section{SEKILAS TENTANG PENULIS}

Saya bernama Christian Oktaviano Karundeng. Lahir pada tanggal 15 Oktober 1995 di Manado, Sulawesi Utara .Anak kedua dari 2 bersaudara.

Saya mulai menempuh pendidikan di SD Advent 3 Paal 2 Manado (2000-2007). Kemudian melanjutkan ke SMP Advent 4 Paal 2 Manado ( 2007-2010). Setelah itu

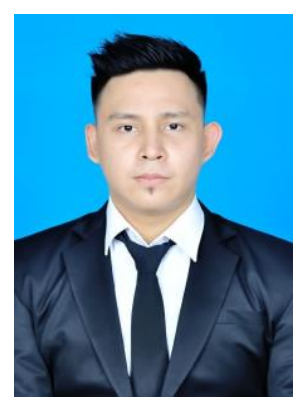
saya menempuh pendidikan di SMA Negeri 1 Manado (2010-2013). Setelah lulus di tahun 2013 saya melanjutkan pendidikan di Universitas Sam Ratulangi Manado, mengambil Program Studi S-1 Teknik Informatika di Jurusan Elektro Fakultas Teknik . Pada tahun 2017 penulis membuat skripsi demi memenuhi syarat Sarjana (S1) dengan penelitian berjudul Rancang Bangun Aplikasi Pengenalan Satwa Langka di Indonesia Menggunakan Augmented Reality yang dibimbing oleh dua dosen pembimbing yaitu Dringhuzen J. Mamahit, ST., M.Eng dan Brave A. Sugiarso, ST., MT. 